\title{
A Survey of the Canals and Water Raceways of New Jersey
}

\author{
Jeffrey L. Hoffman, Ted Pallis, Katie L. Murphy ${ }^{1}$
}

\begin{abstract}
Canals and water raceways played an important role in the history and economic development of New Jersey. Much of the early settlement and industrial activity centered on areas with water transportation and water power. But many of these canals and raceways have been forgotten and lost. A small percentage still exist as abandoned waterways. A smaller percentage are still in use, for either their original purpose or for recreation. A new survey of the current and historic canals and water raceways of New Jersey found 171 of them. The locations are available in a GIS shapefile that indicates their current status (active or abandoned) and condition (wet or dry). The shapefile also shows the locations of locks and inclined planes on the Morris Canal and the Delaware \& Raritan Canal. The number of mapped historical water raceways in an area directly correlated to the interest and activity of local historians. Undoubtedly many more water raceways remain to be rediscovered. This report will be updated by the New Jersey Geological Survey as additional canals and water raceways are identified and reliably located.
\end{abstract}

\section{Introduction}

Canals and water raceways were significant economic influences in pre-electricity New Jersey. The limitations of the roads, especially in wet weather, meant that water transport of bulk items was cheaper than overland transport. Canals provided an economical connection between a resource and a market. For example, the Morris Canal allowed coal to be moved from the coal mines of northeastern Pennsylvania to the furnaces of New York City. New Jersey's canals, however, were eventually supplanted by railroads, a cheaper method of transporting bulk goods.

Water power was the only major source of power available in pre-industrial New Jersey. Whether for grinding grain, cutting lumber, refining ore, or other forms of processing, water power was an essential component of the economy. Raw material couldn't be economically transported a significant distance over the rough roads of pre-industrial New Jersey. Consequently, small mills were located across the state wherever appropriate stream locations could be found.

With time, however, conditions changed. Railroads replaced canals as the most economical transport method for both bulk goods and passengers. Water power, limited by the necessity of being located next to a source of flowing water and by droughts, was replaced by electric power; mills could then be located anywhere a power line reached.

\footnotetext{
${ }^{1}$ Hoffman (Jeffrey.L.Hoffman@dep.state.nj.us) and Pallis, New Jersey Geological Survey, Trenton. Katie Murphy, Hunter Research, 120 West State Street, Trenton, New Jersey 08608.
} 
Over the twentieth century, many of the canals and water raceways were abandoned, followed in some cases by infilling. Defunct canals were especially subject to infilling in cities with a need for more roads.

A new GIS shapefile shows the location of 171 current and historic canals and water raceways in New Jersey. It includes attributes that give the status of each as either active or abandoned. It also indicates whether each is wet or dry. This shapefile can be used to create maps showing the location of the canals and water raceways.

\section{Definitions}

A canal is usually built to allow movement between two water bodies. The Delaware \& Raritan Canal (which allowed travel between the Delaware and Raritan Rivers) and the Morris Canal (from the Delaware River to Newark Bay) are the most important New Jersey examples. Two additional major canals in New Jersey, the Point Pleasant Canal and the Cape May Canal, are part of the Intracoastal Waterway.

A water raceway is a structure built to carry water to and from a water wheel. The headrace extends from an upstream reservoir to the water wheel. The tailrace extends from the water wheel to a downstream point receiving water. For many water raceways the headrace starts at a pond on a stream, diverts water across a bend in the stream to a mill, and then returns water to the stream downstream of the mill. Some mills have no significant raceways, being built next to a dam on a stream.

\section{Criteria for Inclusion in this map}

Humans have modified waterways for a variety of purposes. Six primary criteria were used to determine which waterway modifications were included in this GIS coverage:

1) Structures labeled as canals were included if they were intended to assist the movement of ships between waterways.

2) Structures labeled as water raceways, or which seemed to be water raceways, had to connect a water source with a mill or industrial facility.

3) The structure must have been shown on a current or historic photograph or map with sufficient detail to be mapped on a current aerial photograph. Anecdotal or written information about a canal or raceway without a map or photograph was judged to be too inaccurate for inclusion in this survey.

4) Raceways less than 100 feet long were excluded.

5) Ditches dug for drainage were excluded. This excluded significant lengths of shallow ditches dug in the wetlands and marshes of New Jersey.

6) Channelized streams were excluded unless they were part of a longer canal. 


\section{GIS Shapefile}

A geographical information system (GIS) stores and analyzes data linked to location. A computer program can overlay and display at various scales GIS data sets. The State of New Jersey has an active program to develop and publicize data in this format. (See http://www.nj.gov/dep/gis/.)

A GIS shapefile of current and historic canals and water raceways is now available. ${ }^{2}$ This shapefile includes fields that indicate whether the canal or raceway is active or inactive. All active entries are additionally coded as being wet. All inactive canals and raceways are coded either as being either wet or dry based on recent aerial photographs. Canals and water raceways which could not be located on recent aerial photographs due to development but which can be accurately located on historical maps are coded as abandoned and dry. The metadata for the GIS shapefile provides additional technical detail on the shapefile. $^{3}$

The Morris Canal is inactive, but has both wet and dry segments. The GIS shapefile indicates the location of locks on the Morris Canal and the Delaware \& Raritan Canal. It also shows the location of inclined planes on the Morris Canal.

\section{Sources of Information}

Information on canals and water raceways was developed following six main areas of exploration, listed below. Internet references are given in table 1.

1) The four major canals in New Jersey (defined as the Morris, Delaware \& Raritan, Point Pleasant, and Cape May Canals) are clearly marked on numerous current and historic maps and have been the subject of several books (see for example Veit's The Old Canals of New Jersey). ${ }^{4}$

2) The U.S Geological Survey maintains the Geographic Names Information System (GNIS). All entries for New Jersey that contained "canal," "ditch," or "mill" as part of the place name were located on aerial photographs taken between 1930 and 2002. Each location was examined for any visual remnant of a canal or water raceway.

3) Information from local historians provided significant data on numerous water raceways. In general, the more active the local historical group, the greater the

\footnotetext{
${ }^{2}$ T. Pallis, K. Murphy, and J. L. Hoffman, Canals and Water Raceways of New Jersey. Trenton: N.J. Geological Survey Digital Geodata Series 08-1. http://www.njgeology.org/geodata/dgs08-1.htm (2008). This is the document that will be updated as additional information becomes available.

${ }^{3}$ New Jersey Department of Environmental Protection, Bureau of Geographic Information Systems, 2009; see http://www.nj.gov/dep/gis/.

${ }^{4}$ R. F. Veit, The Old Canals of New Jersey (Little Falls, NJ: N.J. Geographical Press, 1963).
} 
number of documented raceways. ${ }^{5}$ This search was combined with an Internet search that grouped 'New Jersey' with "canal," "canals," "raceway," and "mill." Though not comprehensive, this search was productive.

4) The New Jersey State Library provides access over the Internet to the Digital Sanborn Maps, 1867-1970 collection. These are a series of maps created by the Sanborn Map Company for fire insurance purposes. Water-carrying canals and raceways were noted on these maps. One set of maps for each town was visually examined for canals and water raceways.

5) In 1894, Cornelius Vermeule systematically reviewed New Jersey water power. For each mill he catalogued the owner, stream, location and item(s) produced. This list of mills was cross-referenced with raceways already located. Mills not located were searched for using aerial photography on file with the New Jersey Department of Environmental Protection. Unfortunately, most of the mills listed in Vermeule's report could not be located based on the available data. ${ }^{6}$

6) Several published reports were found during the course of research that provided the locations of additional water raceways. ${ }^{7}$

Many of these searches were of aerial photography displayed on a computer monitor. Thus the location accuracy depends on the photograph quality and the observer's visual acuity. Additionally, abandoned but wet water raceways can appear to be natural hydrologic features, such as partially filled meander loops. This makes visual definition of abandoned raceways difficult in areas where any physical trace of the mill is not apparent on the aerial photograph.

Changing mill ownership presented an additional complication. The available resources refer to some raceways by two or more names. Generally the most recent name was chosen.

\section{Graphics}

Figure 1 shows the canals and water raceways of New Jersey located as part of this survey. The index numbers on figure 1 are keyed to entries in table 2. The Morris Canal and the Delaware \& Raritan Canal are labeled directly on the figure due to their length. The

\footnotetext{
${ }^{5}$ E. T. Lenik, The Tuxedo-Ringwood Canal, unpublished 1965 manuscript on file with the North Jersey Highlands Historical Society.

${ }^{6}$ C. C. Vermeule, Report on Water-supply, Water-power, the Flow of Streams and Attendant Phenomena: Vol. III of the Final Report of the State Geologist (Trenton: The John L. Murphy Publishing Co., 1894).

${ }^{7}$ For example, see C. S. Boyer, Early Forges and Furnaces in New Jersey (Philadelphia: University of Pennsylvania Press, 1931) and R. Hunter, Power to the City, The Trenton Water Power (Trenton: N.J. Dept of Transportation and the Federal Highway Administration, 2005).
} 
graph also shows locks and inclined planes for these two canals. Figure 1 is designed to be printed out on a $81 / 2$ " by 11 " sheet of paper.

Figure 2 adds the name of the canal or water raceway to the graphic. This is designed to be printed out on a larger sheet of paper. ISO B1 size (28" x 40") works well.

\section{Conclusion}

Canals and water raceways were significant economic influences in the industrialization of New Jersey. A survey of current and historic canals and water raceways found 171 of them in New Jersey. This is based on published documents and reviews of aerial photographs. There are probably dozens, if not hundreds, of additional water raceways that have disappeared due to development.

A new GIS shapefile allows users to locate the canals and water raceways and create maps. This shapefile also shows if the canal or raceway is still active or abandoned, and if it is filled with water or dry.

Table 1. Additional Internet links for canals and water raceways source information

\begin{tabular}{ll}
\hline \multicolumn{1}{c}{ Information Source } & \multicolumn{1}{c}{ Internet Link } \\
\hline $\begin{array}{l}\text { Aerial photographs, } \\
1930 \text { and 2002 }\end{array}$ & $\underline{\text { http://www.nj.gov/dep/gis/depsplash.htm\# }}$ \\
$\begin{array}{l}\text { Canals and water raceways of New } \\
\text { Jersey (shapefile) }\end{array}$ & $\underline{\text { http://www.njgeology.org/geodata/dgs08-1.htm }}$ \\
$\begin{array}{l}\text { Digital Sanborn Maps, 1867-1970, } \\
\text { for New Jersey }\end{array}$ & $\underline{\text { http://www.njstatelib.org/Electronic Resources/subject/history.php }}$ \\
$\begin{array}{l}\text { Geographic Names Information Sys- } \\
\text { tem for New Jersey }\end{array}$ & $\underline{\text { http://www.nj.gov/dep/gis/stateshp.html }}$ \\
\hline
\end{tabular}


Hoffman, Pallis, and Murphy

Figure 1.

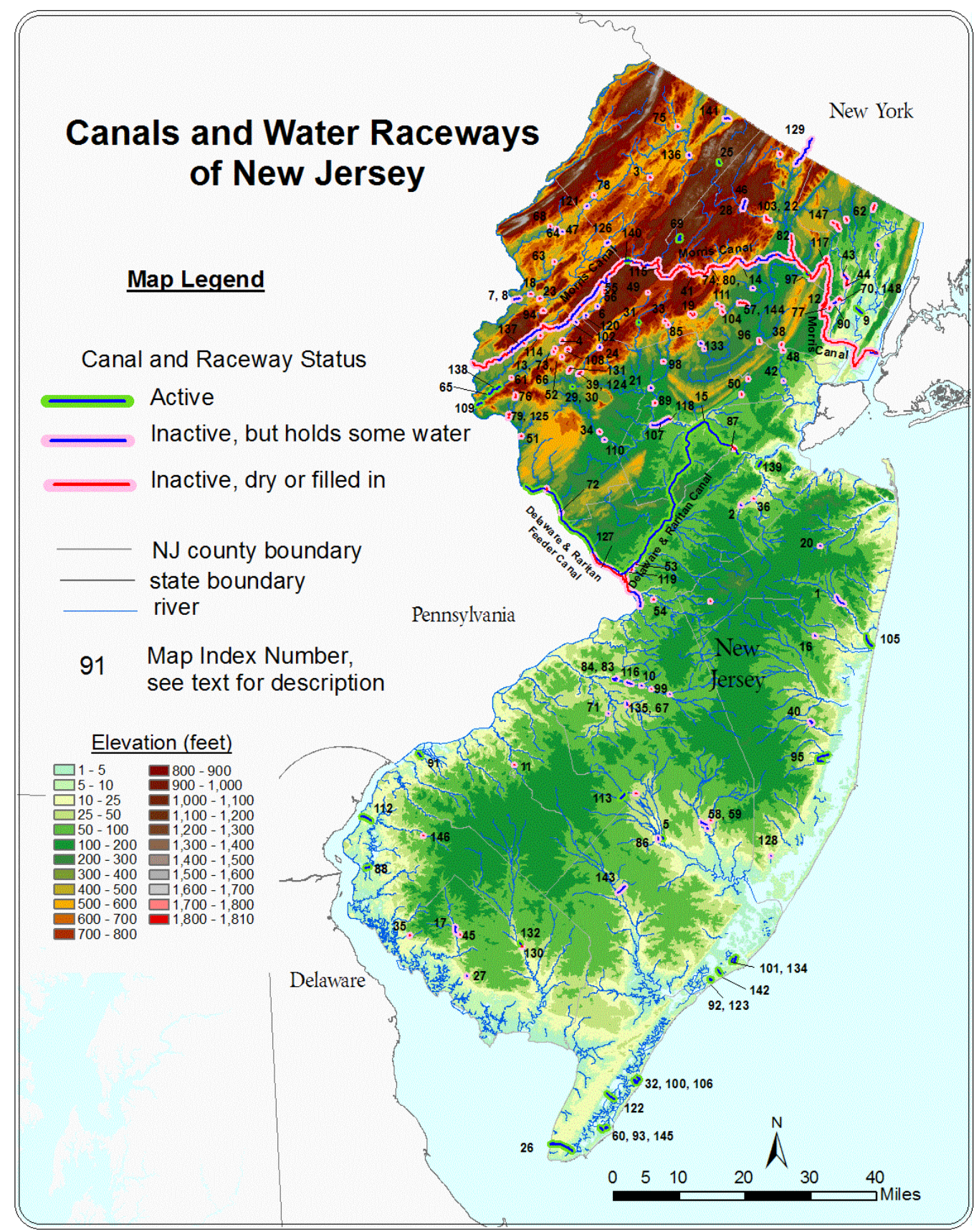


Table 2. Key to map index numbers for the canals and water raceways of New Jersey.

1 - Allaire Canal

2 - American Snuff Company Raceway

3 - Armstrong Flour and Grist Mill

Raceway

4 - Asbury Graphite Mill Raceway

5 - Atsion Raceway

6 - Batsto Village Raceway

7 - Beattystown Mill Raceway

8 - Belvidere Lower Raceway

9 - Belvidere Upper Raceway

10 - Berrys Creek Canal

11 - Birmingham Forge Raceway

12 - Blackwood Raceway

13 - Bloomfield Saw Mill Raceway

14 - Bloomsbury Raceway

15 - Boonton Raceway

16 - Bound Brook Raceway

17 - Brandts Paper Mill Raceway

18 - Bricksburg Iron Company Raceway

19 - Bridgeton Raceway

20 - Bridgeville Raceway

21 - Brook Olyphant \& Co. Raceway

22 - Brookside Main Street Raceway

23 - Brookside Mill Raceway

24 - Bucks Mill Raceway

25 - Burnt Mills Raceway

26 - Butler Hard Rubber Company

Raceway

27 - Butz's Mill/Axford Mill Raceway

28 - Califon Mills Raceway

29 - Canistear Reservoir Feeder Canal

30 - Cape May Canal

31 - Cedarville Raceway

32 - Charlottesburg Raceway

33 - Clinton Grist Mill Raceway

34 - Clinton Red Mill Raceway

35 - Connett Saw Mill Raceway

36 - Cooper Mill Raceway

37 - Cornell Harbor

38 - Cramer Saw Mill Raceway

39 - Darts Mill Raceway

40 - Davis Mill Raceway
41 - De Voe Raceway

42 - Delaware \& Raritan Canal

43 - Diamond Mill Paper Raceway

44 - Dorland Grist Mill Raceway

45 - Double Trouble State Park Mill

Raceway

46 - Dover Iron Works Rolling Mill

Raceway

47 - Droescher Mill Raceway

48 - Dundee Canal

49 - Dundee Raceway

50 - Eastlake Mill Raceway

51 - Echo Lake Channel

52 - Eden Paper Mill Raceway

53 - Electric Light Station Raceway

54 - Fandango Mills Raceway

55 - Flanders Mill Raceway

56 - French's Flour Mill Raceway

57 - Frenchtown Mills Raceway

58 - Glen Gardner Flour \& Grist Mill

59 - Goldens Grist Mill Raceway

60 - Goodall Rubber Company Raceway

61 - Granite Linen Company Raceway

62 - Groveville Cotton Mill Raceway

63 - Gruendyke Grist Mill Raceway

64 - Hackensack Water Co Intake Canal

65 - Hackettstown Water Wheel Raceway

66 - Hanover Cotton Mill Raceway

67 - Harper Hollingsworths \& Darby

68 - Harrisville Water Power Canal

69 - Harrisville Water Power Raceway

70 - Hoffman Canal

71 - Hoffman Mill Raceway

72 - Ho-Ho-Kus Bleachery Mill Raceway

73 - Hope Grist Mill Raceway

74 - Huff Grist Mill Raceway

75 - Hughesville Canal

76 - Imlaydale Mill Raceway

77 - Irick Raceway

78 - Jacksonburg Mill Raceway

79 - Jefferson Canals

80 - Kerman Carpet Cleaning Raceway 
Table 2. Key to map index numbers for the canals and water raceways of New Jersey. (cont).

81 - Kirbys Mill Raceway

82 - L. E. Carpenter Raceway

83 - Lambertville Water Power Canal

84 - Lanes Rag Grinding Mill Raceway

85 - Liondale Bleach, Dye \& Paint Works Raceway

86 - Little Foundry \& Machine Shop

87 - Little York Mills Raceway

88 - Lobsitz Mills Raceway

89 - Long Pond Ironworks Furnace

Raceway

90 - Marthas Furnace Raceway

91 - Middleville Raceway

92 - Milford Mill Raceway

93 - Miller \& Mott, Saw \& Grist Mill

Raceway

94 - Morris Canal

95 - Morris Canal Pompton River

Aqueduct

96 - Mt. Holly Bypass Channel

97 - Mt. Holly Mill Race

98 - Nesbitt Mill/Tiger Distillery Raceway

99 - Nescochague Canal

100 - New Brunswick Raceway

101 - New Cut

102 - New Lisbon Raceway

103 - North Branch Saw and Grist Mill

Raceway

104 - Nutley Memorial Park Raceway

105 - Old Canal

106 - Orient Canal

107 - Osbornes Mill Raceway

108 - Ottens Canal

109 - Oxford Grist Mill and Furnace

Raceway

110 - Oyster Creek Intake Canal

111 - Park Ridge Electric Generating

Raceway

112 - Parrot Mill Raceway

113 - Passaic Valley Water Intake Canal

114 - Peapack Brook Grist Mill Raceway

115 - Pemberton Raceway

116 - Pennsylvania Harbor

117 - Penrose Canal

118 - Penwell Mills Raceway

119 - Pequannock Valley Paper Company

Raceway

120 - Pocahontas Mills Raceway
121 - Point Pleasant Canal

122 - Powerville Felt Roofing Company

Raceway

123 - Prallsville Mills Current Raceway

124 - Prallsville Mills Historic Raceways

125 - Princeton Harbor

126 - Raritan Water Power Canal

127 - Red Mill Raceway

128 - Riegel Paper Company Canal

129 - Rockafellows Mill Raceway

130 - Rockaway Iron Works Raceway

131 - Salem Canal

132 - Saltars Ditch

133 - Sherred-Eckels Grist Mill Raceway

134 - Shippenport Forge Raceway

135 - Smithville Canal

136 - S.U.M. Raceway

137 - Speedwell Lake Raceway

138 - Star Grist Mill Raceway

139 - Star/Murry Rubber Company

Raceway

140 - Stephensburg Mill Raceway

141 - Stillwater Mill Raceway

142 - Stone Harbor Canal

143 - Sunset Canal

144 - Taylor Iron Works Mill Pond and

Raceways

145 - Thomas Grist and Feed Mill

Raceway

146 - Tranquility Mill Raceway

147 - Trenton Water Power Canal

148 - Troy Grist Mill Raceway

149 - Tuckerton Raceway

150 - Tuxedo-Ringwood Canal

151 - Union Canal

152 - Union Furnace Raceway

153 - Union Lake Canal

154 - Van Dorans Mill Raceway

155 - Vandeweghe Tannery Raceway

156 - Venice Lagoon

157 - Vincentown Raceway

158 - Wallkill Roller Flour Mills Raceway

159 - Warnes Grist Mill Raceway

160 - Warren Glen Canal

161 - Washington Canal

162 - Waterloo Grist and Saw Mills

Raceway 
Table 2. Key to map index numbers for the canals and water raceways of New Jersey. (cont).

163 - Wawayanda Canal

164 - West Canal

165 - Weymouth/Makepeace Canal

166 - Whippany Paper Company Mill

Raceway

167 - Wildwood Canal

168 - Woodstown Roller Mills Raceway

169 - Wortendyke Grist Mill Raceway

170 - Worthen \& Aldrin Mills Raceway

171 - Wostbrock Embroidery Works

Raceway 